\title{
DEBATES
}

\section{Fatema Mernissi's writings as a gateway to postcolonial islamic feminisms and intersectionality in the Maghreb}

\author{
Os escritos de Fatema Mernissi como uma porta de entrada para o \\ feminismo islâmico pós-colonial e a interseccionalidade em Maghreb
}

\section{Jessica da Silva C. de Oliveira}

\begin{abstract}
After decades of debate among feminist scholars, there is still a pervasive resistance to serious engagements between Western and non-Western perspectives on feminism and gender. This is even more symptomatic when it comes to islamic feminist scholars. With this in mind, I examine the work of Moroccan sociologist Fatema Mernissi. I argue that her "double critique" to representations of Muslim women in both Orientalist and Moroccan local authorities' discourses performs an intersectional approach to gender that is attentive to how it interplays with class and race, but is also conditioned by cultural encounters. Mernissi's attention to East/Orient and West cultural encounters as constitutive of contemporary gender relations in the Maghreb offers a more historically and culturally informed view on the gender question in Muslim majority societies, and helps to facilitate conversations between Western and islamic feminists.
\end{abstract}

\section{Keywords}

Islamic Feminism; Postcolonial Feminism; Fatema Mernissi; Muslim Women; Intersectionality.

\section{Resumo}

Mesmo após décadas de debate entre estudiosas feministas, ainda há uma resistência generalizada a diálogos sérios entre perspectivas ocidentais e perspectivas não-ocidentais sobre feminismo e gênero. Isso é ainda mais sintomático quando se tratam de estudiosas feministas islâmicas. Com isso em mente, examino a obra da socióloga e romancista marroquina Fatema Mernissi. Argumenta-se que sua "dupla crítica" a representaçóes dominantes das mulheres muçulmanas - seja nos discursos orientalistas, seja nos discursos das autoridades locais marroquinas - é um exemplar de abordagem interseccional atenta às interpelaçóes entre gênero, classe e raça, e em como essa interpelaçáo é condicionada também pelos encontros culturais. A atenção de Mernissi aos encontros culturais entre Oriente e Ocidente como constitutivos das relaçóes de gênero contemporâneas no Magrebe nos oferece uma visão mais histórica e culturalmente informada sobre a questão de gênero em sociedades de maioria muçulmana, o que pode facilitar o diálogo entre feministas ocidentais e feministas islâmicas.

\section{Palavras-chave}

Feminismo Islâmico; Feminismo Pós-Colonial; Fatema Mernissi; Mulheres Muçulmanas; Interseccionalidade. 


\section{Introduction}

My first encounter with Moroccan feminist sociologist Fatema Mernissi was during my Masters. I remember being marvelled at Mernissi's beautiful narrative in Dreams of Trespass - Tales of a Harem Girlhood (1994), a memoir in which she visits her childhood as a middle-class Muslim girl born and raised in a harem in 1940s colonial Morocco. As she conducts the reader throughout important moments of her own stories, she also performs the work of destabilizing stereotypical images of Muslim women, Islam - which, like Christianism and Judaism, is both a religion and a cultural identity from which social norms derive and reflect in people's lives - and Islamic institutions to an envisaged Western audience (MERNISSI, 1994). In a more scholarly-fashion, the author has investigated the sexual dynamics in her society and focused on inequality experienced by marginalized women in works such as Beyond the Veil ([1975] 1987) and Doing Daily Battle ([1984] 1989) - the later consisting of a collection of interviews of Moroccan Women published in French and then translated into 6 languages. Mernissi is known for her versatility and boldness in what touches research themes and methodology, written style and pro- women's rights activism in the North African and Middle East (MENA) region as a whole, but especially in Morocco. Nonetheless, her ground-breaking life work has had little reverberation both in Western feminist circles in general ${ }^{1}$, and in studies focused on gender, culture, and intersectionality from an international/global perspective.

Taking the field of International Relations - the one in which I was trained -, for instance, we can say that we have witnessed at least four decades of debate and research efforts dedicated to highlight the relevance of gender as both a category of analysis and a starting point for theorizing on international and global politics ${ }^{2}$. However, even if we consider the plurality of approaches falling under the "feminist" and/or "gender studies" label - i.e. liberal, Marxist, postcolonial, poststructuralist etc - , there is a remaining resistance to serious engagements with islamic feminism. This is not less true in what regards the willingness to establishing a dialogue among different approaches to gender and to women rights' agenda, but I sense it is symptomatic when it comes to non-Western feminist scholars, in general, and islamic feminist scholars, in particular - even after "intersectionality" has become a buzzword and possible solution to exclusions in the existing debate.

\footnotetext{
${ }^{1}$ The works of American scholars like Miriam Cooke and Margot Badran are exceptions in this matter. ${ }^{2}$ See, for example: Cohn (1987); Enloe (2004, 2014); Ackerly, Stern and True (2006); Tickner (1997, 2010).
} 
Mernissi's attention to cultural encounters between the Orient/East and the Occident/West, and to how these encounters have become constitutive of gender relations in postcolonial societies in the Maghreb (Morocco, Algeria, and Tunisia) and the wholly Middle East is one of the reasons why I believe it is worth reading her work as a point of entrance to understand islamic feminism and, thus, to start filling in this gap $^{3}$. The double critique to Western imperialism and anti-islamic feeling and to Islamic fundamentalism is another important nuance of her life work. Besides, by writing and publishing not only in Arabic, but also languages such as French and English, and promoting her work to audiences in the United States and Europe as also means to deepen her investigation of cultural encounters, Mernissi certainly did not take the experience of her own encounters with "the West" for granted. One can noticed from her reflexivist engagements with this specific topic in Scheherazade Goes West (2001). What may simply come across as intellectual promotion beyond-borders could also be interpreted as a conscious effort at building bridges.

The reasons for resistance by feminist scholars based in the West to engage with islamic feminists can be manifold. To name a few: the fact that, perhaps, many islamic feminist scholars are not writing in English, French or other Western language; the

\footnotetext{
${ }^{3}$ Mernissi has never defined herself as "Islamic feminist" and perhaps would resist the label. The term Islamic Feminism began to be visible in the 1990s in various locations. I find the words of Margot Badran worthy of the following long quote: "It is important to distinguish between Islamic feminism as an explicitly declared project, as an analytical term -- and Islamic feminist as a term of identity. Some Muslim women [...] describe their project of articulating and advocating the practice of Qur'anicallymandated gender equality and social justice as Islamic feminism. Others do not call this Islamic feminism but describe it as an Islamic project of rereading the Qur'an, women-centered readings of religious texts, or 'scholarship-activism' [...]. The producers and articulaters, or users, of Islamic feminist discourse include those who may or may not accept the Islamic feminist label or identity. They also include so-called religious Muslims (by which is typically meant the religiously observant), so-called secular Muslims (whose ways of being Muslim may be less publicly evident), and non- Muslims. Many Muslims use the adjectives religious and secular to label themselves or each other; other Muslims feel uneasy with these terms. It is important to historicise or contextualise the use of these terms [...]" (BADRAN, [200-]). Moreover, I must say that since my first encounter with Mernissi's writing I have been sharing Badran's perception that Mernissi is one of the earliest to articulate Islamic feminism without taking on an Islamic feminist identity. Even though I do not have the intention to articulate nor to borrow someone else's definition of 'Islamic feminism', I believe it is possible to start from the general understanding that by uncovering the foundations of gender inequality, by reinterpreting the Islamic tradition from an egalitarian perspective, and by seeking rights and justice for women together with and/or on behalf of women one can be called Islamic feminist (RHOUNI, 2010). Mernissi fits within such definition.
} 
monolithic (Orientalist) constructions of Islam, Muslims, the Middle East - which, as it is known is not exclusively Arab or Islamic - that prevail in the West; the narrow understanding of Islamism as a religion and not as a historical, cultural and epistemological heritage and frame of reference - just as Christianity in the West -; and, relatedly, the "[...] consistently exclusionary approach on the part of many feminists towards religious women" (SALEM, 2013) even though most islamist feminist actually adopt either a critical eye towards fundamentalist interpretations of Islam or a secularist approach.

On the part of islamic feminist thinkers and women rights activists from the Middle East, many do not describe themselves as feminists because of the perceived Western roots of the term and its association with modernization as Westernization (BASU, 2017; RHOUNI, 2010; TOHIDI, 2017). As some of Mernissi's writings show, not all feminist interventions take the form of self-identified women's movements. For this reason, I would also like to refer to "feminism" with a connotation that encompasses both ideas and their enactments. In this vein, my choice for "islamic feminism" avoiding a capital "I" is inspired by Raja Rhouni's approach to Mernissi's contributions to the debate on gender, women's rights and feminism. The intention is to avoid using 'islamic' as an essentialist qualifier - as it often goes with 'Islamic' - both in what comes to "[...] as 'Orientalist Islamology' and political science, on the one hand, and the canonical construction of "Islam" [...] by orthodox Muslim theologians and jurists, who refuse to consider its plurality and open-endedness" (RHOUNI, 2010, p. 36).

I invite the reader to imagine Mernissi's work as a gateway to a more historically situated and culturally aware view of the gender question and of the evolution of postcolonial islamic feminism in the Maghreb - and in 1980s-1990s Morocco, more specifically. I believe Mernissi's writings can be understood, at least to some extent, as an attempt at articulating an intersectional approach to gender that is also attentive to the constitutive role of cultural encounters ${ }^{4}$.

\footnotetext{
${ }^{4}$ A brief clarification: Although the focus of this paper is on non-Western Muslim women - following Mernissi's own words in her work - it should be noted that there are many Muslim women who consider themselves "Westerners" because they are citizens of Western countries. In this sense, claiming about the need of shedding light upon the experiences of "non-Western women" - as Mernissi herself does bears the risk of naturalizing the idea that Muslims living outside Middle Eastern countries are "outsiders" and "foreigners" to an alleged homogeneous West. However, and again following some of Mernissi's insights, "West" (or the Occident) and "East" (or the Orient, the non-West) are not to be understood as geographical entities exclusively but as mobile sites of cultural, epistemological, and
} 
In the first section, I argue that Orientalist assumptions are still very much in place in Western imaginary and practices towards Muslim majority societies, and briefly situate Western feminism's troubling engagements with the experiences of nonWestern women, especially Muslims. The second section addresses Mernissi's contributions in launching a double critic to both Orientalist and Islamist dominant discourses, and highlighting their complicit in the subalternization of Maghrebian women. I focus my attention on her 1984's book translated to English in 1989 as Doing Daily Battle - an anthology of interviews she conducted with women across Morocco. I highlight aspects of Mernissi's work which I believe may assist us in decentering feminism by turning our attention to other forms of "gender consciousness" - or "subaltern consciousness" - nurturing women's existence (and resistance) across different locales and contexts. In the concluding section, I rely on Mernissi's postcolonial islamic feminism to discuss cultural encounters as a key element for any intersectional approach to gender that purports to seriously acknowledge the complexity of non-Western women experiences and viewpoints.

\section{Western feminism and contemporary representations of non- Western women}

It is known that there has been a growing attention to the Middle East region and Middle Eastern societies' politics and culture - a word that rarely comes in its plural form "cultures" -, especially in the post-September 11, 2001 world and US President George W. Bush's related war on terror. Especially since September 11, 2001, Muslims have been widely conceived a threatening group - “[...] the most homogenized and the mostly troubling [culture] of the Rest" (ABU-LUGHOD, 2002, p. 07), whereas Muslim women symbolize the oppressive, patriarchal and violent character of this culture by being portrayed as powerless, voiceless victims. Along with the United States and its allies' invasions and bloody wars in Afghanistan, Iraq and surroundings, and the security practices directed against "Islamic terrorism" came the "ethical" justifications for such endeavours. Rescuing Muslim women from their oppressing cultures was an important ethical commitment sealed by the American government and allies. Although Western representations of Muslim women have a long and troubling history, as Lila Abu-Lughod (2002) points out, since the beginning

economic power. Thus, rather than a geographical entity alone, the West may be understood as the expression of a structural solidarity between imperialism, ethnocentrism and (supposed) self-sufficiency (See KHATIBI, 1983). 
of U.S. Global War on Terror, the images of oppressed Muslim women in need of being saved became to populate Western imaginary through the media, political leaders, influent people, and experts' discourses and, notably, human rights and feminist groups' activism.

This is very much connected to what Edward Said (1978) problematized as the Orientalism of Western discourse and gaze upon the East/Orient/non-West. Orientalism implies a stereotyped understanding of "the Orient" as a monolith that is not only the opposite of everything that the "West" represents, but also something "right there" to be discovered, explored, subjugated, and controlled. The Orient is, above all, the West's radical "other”. As Said explained in his ground-breaking 1978 homonymous book, Orientalism can function as a political ideology embodied in the distinctions between a superior "West" (the Occident) and "East" (the Orient), a power-knowledge nexus that enabled those speaking and acting from the privileged position of the West/the Occident to generalize, misrepresent and subjugate North African, Middle Eastern and Asian societies. The Orientalist discourse constructs spatial, cultural, and visual mythologies and stereotypes that are often connected to the geopolitical ideologies of governments and institutions and, of course, to the process of knowledge production.

Regarding mainstream feminism in the United States and Europe, if the 1990s can be seen as a moment of revitalization and a shift from domestic to global issues which brought to surface academic discussions and activist mobilizations around issues such as female genital cutting and enforced veiling, from the 2000s on, the Middle East (and Middle Eastern women) has become an important site for the promotion of causes abroad. United Nations international women's conferences, transnational and regional advocacy organizations, and internationally funded non-governmental organizations (NGOs) are also important actors in this movement of turning gender equality and women's human rights agenda into a "global" endeavour (BASU, 2017).

As much progressive and inclusive these movements towards a global agenda for women's human rights and equality may try to be, they are undoubtedly marked by assumptions of "universal goals" for an "universal woman" (SALEM, 2013), as if the experiences of women in all parts of the world and from all socioeconomic and cultural backgrounds could be capture as a singular aprioristic category. What AbuLughod realizes investigating the impetus behind mainstream American feminist activists acting abroad and, more specifically, the boost on such endeavours towards Muslim women after 2001 is that, by promoting causes far from home, they could secure themselves a place in larger political debates around "the role of United States 
as the beacon of humanitarianism" (FARREL; MCDERMOTT, 2005 apud ABULUGHOD, 2002, p. 08). A similar critique is raised by Sara Salem (2013) in her discussion of Western feminism troubling engagements with Third World women, in general, and Muslim women and islamic feminism, more specifically. The construction of those women as "[...] constrained, victimized, poor, ignorant as opposed to Western women who are educated, modern, and free to make their own choices" is what enables the depiction of non-Western women as a singular group on the basis of a supposed shared oppression (SALEM, 2013). Such move automatically assigns the role of heroes (or heroines) to some and victims to others (BRITTAIN, 2006; HUNT, 2006).

Besides, it is crystal clear that knowledge production and the delineation of political agendas on women's rights (in a global, local and/or regional basis) takes place within a global system that is marked by specific relations of power that render some voices audible while others are silenced and effaced. The "power of the word", that is, the power to not only speak and being listened but also to create narratives about historical and political events - and, thus, sediment pervasive images about past and present events as well as possible and desirable futures - is the prerogative of a few. If we take the example of the mainstream narrative about the evolution of modern feminism since the $19^{\text {th }}$ century throughout the $20^{\text {th }}$ century, we have the first and the second "waves" of women's mobilization and feminist thinking as processes taking place exclusively in the West. Although black feminists as well as feminists speaking from developing nations were deemed important during the second wave as issues of class and race gained more attention, they were hardly seen as protagonists (AKBARIDIBAVAR, 2018; KROLOKKE, 2006). Audre Lorde's open letter to Mary Daily, who was another radical feminist thinker at the 1970s, illustrates how the view that all women share the experience of oppression on similar grounds in a patriarchal system can actually encourage blindness to different power hierarchies and to how they produce different experiences of oppression across space, time and bodies:

[...] this serves the destructive forces of racism and separation between women $[\ldots]$ the assumption and myth of white women is the legitimate and sole herstory and myth of all women to call upon for power and background, and that non-white women and our herstories are noteworthy only as decoration, or examples of female victimization. (LORDE, 1984, p. 69). 
In fact, Black American feminists were important voices in advancing the claim that "mainstream feminism" was not, and could not, represent their experiences and demands since it had difficulty in acknowledging how gender coheres with class and race to produce different and complex forms of oppression. By insisting that their realities were far more complex than a simple understanding of womanhood would allow, that they were also black, urban/rural, poor/rich, educated/uneducated and etc, they helped to articulate what later became "the holy triad of feminist studies: racegender-class" (SALEM, 2013). Intersectionality - a term first coined by Kimberly Crenshaw -, would then become widespread among feminist scholars who were working from a poststructuralist or a postcolonial perspective, and would help to add other identities such as sexuality, disability, and culture to the debate (AKBARIDIBAVAR, 2018).

Chandra Mohanty (1988) has written extensively on the production of the "Third World Woman" and the problems that a theoretical view exclusively emanated from "Western eyes" can bring to discussions over the forms of oppression and violence women face around the world. Although the term "Western feminism" is too broad and tends to homogenize the multiple movements that comprise it, it is possible to assert, following Mohanty, that there is a certain body of knowledge carrying on certain underlying assumptions that together compose a general approach or view that can be described as Western feminism. In Mohanty's (1988, p. 61-62) words:

\footnotetext{
Western feminist discourse and political practice is neither singular nor homogenous in its goals, interests or analyses. However, it is possible to trace a coherence of effects resulting from the implicit assumption of "the West" (in all its complexities and contradictions as the primary referent in theory and praxis. My reference to "Western feminism" is by no means intended to imply that it is a monolith. Rather, I am attempting to draw attention to the similar effects of various textual strategies used by particular writers that codify Others as non-Western and hence themselves as (implicitly) Western.
}

The discursive construction of Muslim women and of Middle Eastern women in general is in connection with the prevalent construction of Third World women that Mohanty (1988) is problematizing. They are assumed to belong to the category of the oppressed, victimized, and backward, especially if stereotypical understandings of Islam as essentially oppressive and violent are at play. This construction serves to hide the specificities of each woman's lived reality and the complexities of their 
political, economical and, importantly, their cultural contexts, keeping the ongoing debate conditioned by (Western) particular notions of agency, autonomy, subjectivity, and progress instead.

As Fatima Mernissi herself pointed out, the myth of the exotic (and erotic) East was constantly echoed in European paintings, writings and travelogues, which depicted Arab and Muslim cultures as an intangible difference to the West due to their supposed irrationality, mystery and promiscuity (MERNISSI, 2001). As Anne McClintock (1995) and Ilan Kapoor (2015) already highlighted, projections of the West's internal mistrust of women and anything feminine onto a racialized and sexualized non-West (and non-Western Others) are constitutive elements of the colonial desire leading to colonial and imperial interventions conducted by the West. The assumptions nurturing ideas and goals such as unveiling Algerian women back to colonial years in the Maghreb (FANON, 1965) to saving Afghan and Iraqi women in the context of the war on terror (BRITTAIN, 2006; HUNT, 2006) are all parts of the construction Said named as "Orientalism". Although Said's approach is not exempt from criticism", he insightfully pinpoints the fact that Orientalism has much less to do with the "Orient" than with the projections of West's masculine, homophobic and misogynist anxieties on the East/non-Western subjects (SAID, 1978). And even though I started this section discussing how U.S. war on terror perfectly illustrates the gendered and racial dimensions of the Orientalist discourse towards Middle Eastern societies and individuals, the underlying discourses of saving (and unveiling) oppressed Muslim women are by no means new. As Franz Fanon discusses in A Dying Colonialism, Algerian women's veil was turned into a symbol of those women's oppression by their "backward" patriarchal societies (FANON, 1965; WOODHULL, 1993). A symbol which not only revealed the French colonizer's profound sexism and racism against Maghrebian societies, but also worked well as to justify colonialism as these women needed to be saved.

\footnotetext{
${ }^{5}$ Critics of Edward Said's approach say that the same problematic representation of "the Other" goes for his portrayal of the West/Occident as a homogeneous, fixed, and knowable entity. However, one should consider that "[...] although the structures of representation are similar [...] there is one big difference between Orientalism and Occidentalism which is power, i.e. that the west had, and continues to have, the most powerful voice in representing the West and the rest throughout the world. Historically the influence of Orientalist representations of the world has been much greater than that of Occidentalist accounts" (SHARP, 2006, p. 27).
} 
Thus, women's struggles and the question of women's rights in Muslim majority societies "[...] is embedded within this long-standing orientalist epistemology that sees women's condition as a marker of the Arab world's backwardness" (PRATT, 2016). The problematic assumption of Muslim and Arab societies' endemic backwardness also endorses the idea that women live in a state of pervasive victimization and silence in those spaces. However, what is missing from this picture is the "[...] structures of power based particularly on class and nationality" (very much connected to a history of colonialism and imperialism), and "[...] the role of global political economy and geopolitics in the reproduction of these intersecting hierarchies" (PRATT, 2016). Moreover, it depicts the causes of women's only in terms of their "subordination to Arab cultural values and beliefs" and implies that "the 'West' sets the civilizational standard for women's rights" (PRATT, 2016).

In addition, the focus on the supposed pioneering of American feminists (say $19^{\text {th }}$ century suffragists) and on events happening in Western societies that is implicit in the narrative of feminist "waves" helps to perpetuate the image of non-Western women - especially from Africa and the Middle East - as inert, backward and victimized. Therefore, this narrative focused on the West and Western women's experiences misses at least two things: many women engaging in struggles for gender equality across the world do not describe themselves as feminists (BASU, 2017); and in most parts of the MENA region, women's activism cannot be reduced to resistance against patriarchy on the same ground as established within Western feminist intellectual and activist circles (AHMED, 1992; MERNISSI, 1987; 1989; PRATT, 2016). Besides, as Marnia Lazreg argues, the Orientalist discourse endorsed by some Western feminists have produced 'Islam' as the only explanatory factor behind the tragic conditions of many subaltern women in these societies (LAZREG, 1994, p. 15 apud RHOUNI, 2010, p. 26). In this sense, a close look to the works of islamic feminist thinkers can bring depth to debates on gender equality and women's rights across the world, drawing our attention to intersectionality not only in terms of class, race and gender, but also in terms of how these dimensions cohere with culture to produce specific forms of oppression in different places, times and bodies within the broader scope of imperialism and global capitalism (AKBARI-DIBAVAR, 2018).

Although much has been discussed on how the experiences of non-white women still have been marginalized and silenced even within feminist scholarship and feminist activism in the West, little has been written on the parallel struggles to achieve gender equality and end violence against women taking place in non-Western societies - and notably women from the MENA region. In this sense, just like "Black 
feminism", islamic feminism may be seen as a critique of the supposed universalism of feminism. The works conducted by islamic feminists grounded on the experience of subjects who are often excluded or who do not fully accept the ideas and paths contained in such "universalism" may bring important revisions to commonsensical views about Muslim women, and thus, introduce another element of diversity to this complex debate. With this in mind, in the next section I will turn to Fatima Mernissi's writings and contributions to this debate.

\section{Cultural encounters and subaltern consciousness in Fatima Mernissi's Doing Daily Battle}

The theme of East and West encounters as a constitutive dimension of Moroccan and, to a larger extend, Middle Eastern (colonial and postcolonial) history is a remarkable aspect of Fatema Mernissi's writings, especially in her late 1990s and early 2000s books ${ }^{6}$. She focuses on the lasting antagonisms between the so-called East/Orient/non-West and the Occident/West and attempts to rethink difference and otherness by emphasizing cultural complexity over homogenizing conceptions of East and West encounters, destabilizing Western representations of Islam and Islamic institutions. In this aspect, Mernissi gives especial attention to how "Muslim woman" is an important signifier within these representations.

Although less well-known, some of her earlier writings also grow on similar grounds. In this section, I build up on this important aspect of Mernissi's work, that is, her attention to cultural encounters, and, importantly, her efforts to destabilize dominant representations about Muslim women, bringing to crisis the unified mythical-like female identity normalized or invented both in the West and in postcolonial Morocco. I thus focus on the resonant and yet less explored work of hers: Le Maroc Raconté par ses Femmes (1984 [translated and published in 1989 as Doing Daily Battle - Interviews with Moroccan Women]). I argue that the element of cultural encounters between East and West is a constant feature of her writings through which she manages to target both Orientalist and local patriarchal imagery and discourses on women, performing what Abdelkebir Khatibi (1983) called "double critique" and Raja Rhouni (2010) paraphrased as a "multiple-front analysis". By performing this work of double critique, Mernissi brings to the fore elements that help to decenter feminism and to be attentive to other forms of "gender consciousness" - or "subaltern

\footnotetext{
${ }^{6}$ I have already engaged with this particular aspect of Fatema Mernissi's work elsewhere (OLIVEIRA, 2019, 2020).
} 
consciousness" - nurturing women's existence (and resistance) in different locations and contexts.

Doing Daily Battle is a sociological study based on the accounts of women across different parts of Morocco and brings a critical view on the effects of both postcolonial state's modernization policies and foreign adjustment policies on underprivileged women. There, it becomes clear that in Mernissi's perspective, one can only understand Morocco's postcolonial state's modernization policies and their impoverishing effects on local people if they are seen through the broader lenses of the expansion of capitalism and the complicated power relations nurturing such expansion across the globe. As the discussion in the last section shows, the construction of nonWestern peoples as inferior and backward is, to paraphrase Walter Mignolo (2011), an obscure side of Western modernity and, relatedly, of the growth and expansion of capitalism at the expenses of Third World societies' exploitation and controlling by the richer nations of North America and Europe (ESCOBAR, 1995). Mernissi gives attention to such perverse effects taking into account the experiences of Moroccan women.

Borrowing Raja Rhouni's (2010) words, the work performed by Mernissi in Doing Daily Battle can be read as a postcolonial subaltern feminist historical account of Morocco. It is mainly composed of transcriptions of the author's interviews with "unrepresented women" (in the author's own words). Interviewees' testimonies give us a glimpse of what must have looked like to live under their skin, since the way how the interactions between interviewer and interviewee were transcribed culminates in an emotionally inflicted, conversational narrative. At some points, the reader might even feel like she became acquainted with the speaker of the hour, as the interviewer leaves us with the feeling that she had intervened little and simply let those women speak. The most recurrent themes along the book are usually connected to important aspects of their life stories and day-to-day activities such as the location where they were born; their relationship with relatives, neighbours, and family friends; sex division in daily chores, house budgets, marriage, access to public spaces etc. Even though Mernissi does not make clear her criteria in selecting her interviewees, it is noticeable that there is a plurality in what comes to class and life income, location, educational level, and age (MERNISSI, 1989).

It is noticeable how the collection of stories intersect in the ways they end up by upsetting the essentialist category of "Muslim woman" that prevails in Western imaginary, as well as of "Moroccan woman" as built into the state's "scientific discourse" (i.e., the 1957 Moudawana, national statistics etc.). The traditional code of 
family law, for instance, legitimised practices such as forced marriage and polygamy and thus contributed to the subjection of women. It was only reformed by 2004 after much pressure from a reformist movement led by L'Union de l'Action Féminine (MOGHADAM, 2017). As highlighted by Mernissi in the preface of the book, Moroccan Family Law was designed solely by men and since its inception was not representative of the majority of the population, that is, "women of the peasant masses" who "[...] did not have the option of being supported by their husbands, but had to work very hard" (MERNISSI, 1989, p. 02). And yet, article 115 of the Moudawana established that "[...] every person provides for his needs through his own resources with the exception of the wife whose upkeep (nafaqa) is incumbent on her husband" (apud MERNISSI, 1989, p. 02). As we can notice from the interviewees' words, they all see themselves - with the exception of Batul Binjalluna, who was confined in a "harem" - as active participants in the economic life of the family, independent of the income and social standing of the husband (when there was one).

Rabi'a's story, a teacher employed by the Ministry of National Education, is specially interesting to mention here, as she explains that she was the main provider of the house during her marriage years, and after its failure, she linked her decision to get a divorce to the fact that she had means to earn a living. Thus, what the stories show the reader is that not only the majority of men do not support women and their children according to the concept of nafaqa, but that women also have always been important agents of the country's economy and development, despite of being constantly assailed by social forces such as gender inequality in all spheres of their lives, unemployment, illiteracy, poverty, and degrading jobs. Such realization leads Mernissi to affirm that the discussions on the need "to integrate women into development" going on at the time made the wrong assumptions that development had already taken place (despite Morocco's high levels of illiteracy and poverty and low levels of popular political participation, especially by women) and women were not part of it (MERNISSI, 1989, p. 07). In other words, in the dominant national narrative, women are deprived of any subjectivity beyond that of a "consumer and inactive being" (RHOUNI, 2010, p.77).

The problematization raised by Mernissi in the preface and further developed in the interviews is not divorced from a bigger picture that goes beyond Morocco's 1980 s context. If we pay attention to the book's original title, Morocco raconté by sas 
femmes ${ }^{7}$, for example, it might seem that it addresses "[...] a local androcentric discourse and ambitions to write a counter history of Morocco" (RHOUNI, 2010, p. 146). However, as soon as we begin to read the interviews, it does not take much effort to notice that the book also contains a powerful critique to the heritage left by decades of French colonial exploitation in the Maghreb (LAROUI, 1977; WOODHULL, 1993). Thus, another contribution to Mernissi's work is highlighting that the injustices denounced by those women are not endemic. Her interviews with poor woman in rural and urban areas bring to light the other side of colonial linear tale of development and profess that the modernization project carried out by the post-independent state did little - if anything - to improve these women's life conditions. As some testimonies denounce, the introduction of a new economic system based on technology and machinery by the so-called modernization process only exacerbated the common perception of peasant women as economically inactive by further devaluing their manual work. Manual labor in general also became commonly associated with cultural backwardness, which also lead to the devaluation of rural women. These same women were also prevented from any opportunity of social ascension, since they were denied access to education and, not rarely, forced into rural exodus.

This point is more thoroughly explored by Mernissi in her first book, Beyond the Veil. According to her, the way the post-independent state retained the shari'a in the 1957 Moudawana - and thus women's inferior legal status - become important symbols of the state's Muslim identity and, thus, of its postcolonial national ethos (MERNISSI, 1987). Put differently, women's rights are caught within the state's identity politics, and reflected a reaction to the colonial discourse on women (WOODHULL, 1993). As a result, women's liberation is considered by the state as solely a religious and moral problem rather than an economic and social one (MERNISSI, 1987, 1989). This perception is in tune with Leila Ahmed's argument that the call for a return to an "authentic" Islamic culture in Muslim majority societies is a clear response to the aggressive colonial discourse - and to more recent Western incursions into MENA societies such as U.S. and its allies' "war on terror"-, which frequently appeals to women's status in order to undermine Islam and indigenous cultures.

\footnotetext{
${ }^{7}$ Interestingly, the title of the edition published in France is Le Monde n'est pas un harem, and perhaps denotes Mernissi's strong commitment to desmystifying Western fantasies related to Muslim women living in a world of pleasure, eroticism and idleness as depicted in Western (misguided) dominant images of harems.
} 
The Islamist position regarding women is also problematic in that, essentially reactive in nature, it traps the issue of women with the struggle over culture - just as initiating colonial discourse had done. Typically women - and the reaffirmation of indigenous customs relating to women and the restoration of the customs and law of past Islamic societies with respect to women - are the centerpiece of the agenda of political Islamists. (AHMED, 1992, p. 236).

In this regard, Mernissi also highlights the instrumentality of the idea of "liberating women" to the champions of the movement of anticolonial resistance ${ }^{8}$. After national liberation, nationalists had to demonstrate their capacity to carry out the modernization project. However, even though the need to liberate all powers of society, including women, was a constitutive part of the project, after national independence was achieve nationalists did not choose for "modernity" as a project based on the principle of gender equality. As some of her interviewees tell us, the result was a modernization plan in which women's employment and education were at some points articulated as a priority while patriarchal hierarchical relations between men and women were not only maintained but also encouraged by new social arrangements.

It is also interesting to notice how the stories transcribed in Doing Daily Battle bluntly defy Western most deep-seated stereotypes and fantasies regarding Muslim women. If, on the one hand, there are moments the female reader simply identifies with them as they narrate the joys and pains of being a woman in a patriarchal world, on the other hand, they also document the specificities of being a woman in 1980s Morocco, considering the points of view of these women themselves - which are contingent to the interviewee's social class and other aspects of her personal background. Mernissi relies on these and other actual women's accounts throughout her lifework to deconstruct stereotypes and simplistic discourses of truth regarding

\footnotetext{
${ }^{8}$ In this matter, as Rhouni (2010, p. 55-56) explains, "Mernissi is one of the first Arab feminists to have presented a postcolonial feminist revision of the discourse of Arab and Moroccan nationalism. Her analysis of gender relations postindependent Morocco introduces a more radical vision than the one inherent in the project known as 'women's liberation' as articulated by the Moroccan nationalist movement through its leader Allal al-Fassi (1910-74) in his book Al-Naqd al-dhati.Mernissi's critical decoding of the 'progressive' discourse of al-Fassi and of the Arab League's preliminary outline, 'the Arab Charter,' which a committee composed of Arab male nationalists, among them al-Fassi, draft ed in 1948 and which advocates the liberation of women, highlights their patriarchal and bourgeois limitations".
} 
"Muslim women" broadcasted not only by local androcentric social circles and authorities but also by Western intellectuals, media, and, not rarely, by Western feminists.

In this respect, it is worth examining how she deconstructs the term "harem", which became famous in Orientalist narratives as a space of pleasure inhabited by passive, lascivious and sexually available women. For the reader who is unfamiliar with Moroccan and other Middle Eastern cultures, Batul Binjalluna's, Mariam Talbiya's and Rabi' as childhood and teenagerhood memories transcribed in Doing Daily Battle make Orientalist fantasies about harems and odalisques look simply absurd (MERNISSI, 1989). Except for women's seclusion and expected obedience to their partner and elder male relatives, the word "harem" has nothing to do with the Western prevailing images that inspired the paintings of famous artists such as Matisse, Ingres, Delacroix, and Picasso, or Hollywoodian movies industry (MERNISSI, 2001). It actually describes a traditional urban household, usually located in the Medina (the old city), and inhabited by a middle class or upper-class extended family. In her semiautobiographical/semi-fictional narratives in Dreams of Trespass and Scheherazade Goes West, Mernissi addresses more thoroughly the relationship between what she calls "fictional" and "factual" harem. In her own words, "( $m$ )y harem was associated with a historical reality [while] [t] heirs was associated with artistic images... [which] reduced women to odalisques (a Turkish word for a female slave)" (MERNISSI, 2001, p. 14).

Another important point highlighted in Doing Daily Battle is how women who lived in this type of household actually experienced confinement and other expressions of power relations differently. While for a young girl from a poor family living in a harem meant being turned into a servant for other (richer) family - and happen to include episodes of rape, forced abortion, and ostracism especially by the other women in the harem (Mariam Talbiya's interview) -; for others, the harem was a sign of prestige and an experience of a comfortable, fulfilled life (Batul Binjalluna's interview). Or even a short childhood experience to which they were indifferent (Rabi'a's interview) (MERNISSI, 1989). The same is true for the female characters in Dreams of Trespass. if, on one side, we have Lalla Mani (the main character/narrator's grandmother), who accept and normalize harem life; on the other side is the child narrator and her mother, who not only refuse this reality but also develop strategies aiming to disrupt male authority and other pillars sustaining the harem (MERNISSI, 1994). Thus, Mernissi's interviewees in Doing Daily Battle and her (semi)fictional characters in Dreams of Trespass come to complicate the Orientalist narrative by 
highlighting female resistance rather than searching to represent the "truth" about the harem.

It is noteworthy that the word "harem" is currently unfamiliar and barely used in Morocco, as the space the word designates, that is, an urban upper and middle-class household, has disappeared from Moroccan today's reality. This has led to accusations against Mernissi as someone who writes for the West and capitalizes on Orientalist fantasies. The word "harem" as well as the fetish image of veiled women and half-naked odalisques are, in fact, constant elements on the titles and covers of Mernissi's books, especially the French editions. The edition published in France of Doing Daily Battle, for instance, received the curious title "Le Monde n'est pas un harem" (The world is not a harem), while the French translation to the English original Sheherazade Goes West is "Le Harem et l'Occident" (The harem and the West)". This surely makes Mernissi an easy prey to accusations of nurturing the same Orientalist discourse she intends to deconstruct. In Carine Bourget's critical addressing to Mernissi's work she argues, for example, that this attitude undercuts the importance of the author's feminist project since she opted for overemphasizing "the antiquated and exceptional practice of the harem" while "[...] pass[ing] over some important developments in Morocco and the Arab world, such as re-veiling and economic exploitation of poor women" (BOURGET, 2013, p. 32). However, I disagree with Bourget and Mernissi's other critics in this matter for, as soon as one begins to actually read her work, it becomes clear that the content comes precisely to demystify these stereotypes and fantasies. I feel that Mernissi was very much aware that the work of deconstructing Western cliché representations of Muslim societies (as one of the initial necessary steps to enable cultural dialogues and replace Orientalist monologues) could only be accomplished if people actually read her work. I think it was all a matter of strategy to reach Western audiences - by foreign editors (RHOUNI, 2010), for sure, but perhaps by the author as well.

The veil is another constant signifier populating Mernissi's writings and, similarly to the theme of the harem, her early works adopted a much blunter tone of disapproval (RHOUNI, 2010; WOODHULL, 1993). Going through the questions posited by Mernissi while conducting the interviews in Doing Daily Battle, for example, the reader may at some points have the awkward feeling that she is obsessed

\footnotetext{
${ }^{9}$ An image of a veiled woman appears on the cover of Le Monde n'est pas un harem, while an image of an odalisque is on the cover of Le Harem et l'Occident.
} 
with it and sometimes conveys the act of wearing the veil (either by imposition or by choice) as an old-fashioned sign of subservience. All despite the fact that her interviewees not always seem to share this preoccupation (MERNISSI, 1989). In the occasion, the author missed the opportunity to address one important point surrounding the veiling question - especially if we put colonial encounters in perspective -, that is, the way Muslim women and girls' lives are entrapped in a struggle between secularist and defenders of Islamic customs without their concrete interest being taken into account at all.

Though, as noted by Rhouni (2010), there is a shift in the way Mernissi deals with these themes in her later works. From the late 1980s on there is a shift from a more "radical" Marxist-inspired secularist feminism to a "soft" islamic feminist tone in her writings. According to Rhouni, one of the explanations is that, by that time, Mernissi turned to a new interlocutor: the Islamists and their conservative discourse on gender relations and women's place in Muslim societies (RHOUNI, 2010). I would also add Western intellectual debates on gender and politics in Middle Eastern and North African societies in general as important interlocutors in this second phase of her work. Facing these two main interlocutors, Mernissi's started to adopt a "islamic feminist" standpoint that does not assume Islam as essentially hostile to women's rights, but rather a source for promoting equality ${ }^{10}$. In this sense, Mernissi's shift perhaps is also a symptom of the East-West encounters she herself experienced as a Moroccan feminist intellectual travelling across Europe, North America and North Africa, and who carried on the burden of being either the cultural other or the dissident voice. Part of her feelings of strangeness, curiosity and sometimes outrage related to these experiences are also documented in her writings (MERNISSI, 2001).

Despite these shortcomings, I still consider Mernissi's work as a major demystification of the fantasies that nourish the structures of power and desire conditioning the relations between men and women across different cultures and societies. On the one hand, the memories and stories told by the women interviewed by Mernissi contribute to create a picture of Moroccan women that is opposite of Orientalist old and new stereotypes about Muslim women as passive and somewhat frozen in time, denouncing the forms of oppression they face in a daily basis, and

\footnotetext{
${ }^{10}$ Notably, Rhouni names this phase of Mernissi "Islamic feminist", with a capital "I", due to the author's thorough engagements with Islamic texts and customs as sources to understanding and rethinking contemporary Muslim majority societies. However, I still interpret her work as mostly secular but more openly embracing an Islamic cultural identity - and, thus, maintain my choice for "islamic feminist".
} 
highlighting the means they have found to fight back and survive. On the other hand, they also offer a subaltern feminist counter history of postcolonial Morocco, since the main themes highlighted - e.g., family, education, development and economic life, job market, political institutions and popular participation, etc - are approached from the point of view of those who are usually disregarded by state policies and data collection (MERNISSI, 1989). The stories told in Doing Daily Battle not only reflect the personal experiences of each interviewee and the ways they sometimes open up and sometimes close down to the interviewer's questions and provocations, but they are also related to a specific time and place, and articulated by subjects whose voices are hardly listened. And yet, Mernissi's denunciation of the economic exploitation of subaltern women in 1980s Morocco "[...] does not aim to produce these women as essentially victims" nor heroines, "[...] but rather purport to draw attention of policy makers and development planners to the needs of economically dispossessed women" (RHOUNI, 2010, p. 102-103).

Mernissi's interviews also underline that after independence came and, together with it, the realization that the improvement of women's rights would not come along, Moroccan women have become even more aware of their economic, legal and political disadvantages. Young women were more openly rejecting some constraining "traditional" values and therefore challenging deep expressions of patriarchy in the microcosmos of their households and working places, in a daily basis. According to Rhouni (2010), women's awareness of their oppression and their means of resistance as narrated by Mernissi are indications of the formation of a "subaltern consciousness" in postcolonial Morocco - to borrow Zakiya Pathak and Rajeswari S. Rajan's (1992) phrase coined after Gayatri C. Spivak. In this sense, "subaltern consciousness" is not a synonym for the Marxist notion of "class consciousness" and the power of organized resistance and subversion it implies. Despite Mernissi's Marxist influences by the time she conducted the interviews and wrote the preface to the 1989 translated edition, in her perspective, resistance does not necessarily imply dissidence and collective mobilization. Even though the majority of the women interviewed seems very much aware of their marginalization, the reader gets the sense that they are also conscious about their inability to fully transform their realities individually, or collectively. In some cases, rebellion and survival were two sides of the same coin, and the tactics deployed did not come with a "feminist" label - even though they were aimed to confront patriarchy and result from the awareness of women's inferior status and the need for women's empathy and solidarity towards each other. 
Thus, the "subaltern consciousness" I am referring here - following Rhouni's and Pathak and Rajan's insights - "[...] comes into being in response to and through the investments of a hegemonic or dominant consciousness" and "can perhaps only be described as a subject-effect" (PATHAK; RAJAN, 1992, p. 268). However, there are also many examples of women's oppression by other women due to aspects related to class and/or cultural difference in Doing Daily Battle - thus the importance of acknowledging how power structures, or "hegemonic consciousness" operate in complicated, circumstantial ways.

The inevitable question of representation emerges at this point as one may wonder whether the subaltern can be heard by Mernissi - to paraphrase Spivak's (1988) emblematic phrase. To illustrate, we can resort once again to the author's problematic construction of the veil and, as a consequence, "veiled women". Generally speaking, the veil as a signifier appears in Mernissi's works - in her Marxist-inspired secularist early phase as much as in her islamic feminist later interventions - with a monolithic negative meaning, equating it with women's oppression and male control over women's bodies. In Lamia Zayzafoon's (2005) perspective, this negative connotation of the hijab in Mernissi's feminist account is the result of her "double privilege of class and Western education," which allowed her "[...] to speak on behalf of all Moroccan women and equate women's emancipation with unveiling". For Zayzafoon, by conceiving the veil essentially as a symbol of female oppression, Mernissi ends up side by side with "Western colonial feminism" (ZAYZAFOON, 2005, p.20). Such accusations are not ungrounded, as at some points Mernissi does suggest that the women interviewed by her also recognize the veil as symbol of subordination and oppression - even when such view is not openly stated by the interviewee. The veil as an instance of free choice, whether as an expression of religious faith, class, or a sign of national or pan-Arab solidarity (WOODHULL, 1993) is not considered by the author. Thus, women who choose to veil is an absence and a signal that they may have their agency denied even in the writings of a native postcolonial feminist.

To this same point, it is also interesting to notice how "Mernissi's authorial consciousness [...] is felt at the level of form with her voice framing the transcribed interviews" (RHOUNI, 2010, p. 116). On the preface, she assumes, for instance, that she felt the need to adapt parts of their interviewees' accounts for the sake of "readability" (MERNISSI, 1989). In this sense, Mernissi's tendency to highlight her own subjectivity is a double-edged sword, as what the author thinks as reflexivity may come across as an exaltation of her own subjectivity at the expense of her interviewees. Or, perhaps, she is prey to what some postcolonial thinkers call "the guilt" of Third 
World writers who are committed to an emancipatory cause (TRINH, 1989 apud RHOUNI, 2010) ${ }^{11}$. On page 18, for instance, she states:

I cannot be objective toward an illiterate woman because I have a very special relationship to her: I identify with her. I was born in 1940, and very few Moroccan women of that generation have had access to writing and still fewer to advanced education.... For me trying to give voice to the illiterate woman is to give voice to this self of mine which should have been doomed to the ancestral silence. (MERNISSI, 1989, p. 18).

In this sense, I agree with Spivak's (1988) assumption that representation of the "subaltern" is not possible, "[...] neither is subaltern consciousness retrievable by simply attempting to make the subaltern speak in order to capture her worldview" (RHOUNI, 2010, p. 111). Thus, "subaltern consciousness" is by no means an identity or subjectivity, as one "[...] shall find not a unified, freely choosing, purposefully changing subject, but a palimpsest of identities, now constituted, now erased, by discursive displacements". In other words, Mernissi and others engaged in a similar task, can only produce the subaltern's "subject-effect" (PATHAK; RAJAN, 1992, p. 268).

These critical considerations should not be seen as an attempt to diminish Mernissi's valuable contribution. Also, recognizing that "[...] every discourse that breeds fault and guilt is a discourse of authority and arrogance" (TRINH, 1989, p. 10 apud RHOUNI, 2010, p. 118) is not affirming that all power discourses produce oppression equally. As an intellectual who chose to dedicate great part of her life work to listening to other women's voices - especially poor, illiterate women -, Mernissi could only address the subaltern's subject-effects. Reflecting upon this very same point is also at the core of any possibility of dialogue between feminists from different locations, cultures, socioeconomic background, and intellectual standpoints.

\section{Final Remarks: islamic feminism and intersectionality}

As discussed in the last section, Mernissi's postcolonial islamic feminist stance is not exempt from limits and shortcomings. However, together with other emblematic postcolonial feminist thinkers and activists such as Nawal El Saadawi, Huda Sha' rawi,

\footnotetext{
${ }^{11}$ Although the theme does not always easily appear on the surface of his powerful narrative in The Colonial Signs of International Relations (2012), I believe Himadeep Muppidi's book is also a reference to acknowledge on Third World/Non-Western intellectuals' guilt.
} 
and the more recent interventions by authors such as Leila Ahmed, Margot Badran, Miriam Cooke, and Lila Abu-Lughod, Mernissi performs the necessary work of producing "a discursive space" in which the critical voices of Muslim women can be heard and disseminated. Her work shows that women trajectories are much more complex than statistics is able to measure, or that dominant all-encompassing understandings of agency and emancipation can grasp. In Doing Daily Battle, the book on which I focused here, Mernissi documents in detail women's role in the home, the workplace and in the streets, describing the challenges they faced in 1980s Morocco. The women interviewed by her could easily fall under either of the opposing labels "victims" or "heroines", but she rather treats them as complex subjects and relevant living witnesses and agents of a given context.

As a postcolonial feminist thinker, Mernissi inhabits an enabling in-between space from where she could perform a double critique, that is, a critical stance towards both a Eurocentric Orientalist discourse and an ethnocentric local discourse, questioning "[...] both colonial and indigenous mythical narratives about the 'emancipation' or 'liberation' of [...] Muslim women" (RHOUNI, 2010, p. 47). In this sense, Mernissi's engagements in a double critique allows her to visit the ways in which colonialism, nationalism, the post-independence state, and globalization processes have contributed to the "invention" of Muslim women. In doing so, she uncovers how these forces combine to silence women's voices by capturing their subjectivities under a monolithic problematic signifier whose main effect is the effacement of women as key political and economic actors in their respective societies. Mernissi's revisiting of modernity's twin discourses of colonialism and nationalism as solutions for the emancipation of non-Western women in the foreword to the revised edition of Beyond the Veil is especially illustrative of what her double critique consists of. The foreword is provocatively entitled "A Note to the Western Reader":

Is there a nascent female liberation movement similar to those appearing in Western countries? This kind of question has for decades blocked and distorted analysis of the Muslim woman's situation, keeping it at the level of senseless comparisons and unfounded conclusions. It is a wellestablished tradition to discuss the Muslim woman by comparing her, implicitly or explicitly, to the Western woman. This tradition reflects the general pattern prevailing in both East and West when the issue is 'who is more civilized than whom'. [...] I am not concerned with contrasting the way women are treated in the Muslim East with the way they are treated in the Christian West. I believe that sexual inequality is the basis of both 
systems. My aim is not to clarify which situation is better. (MERNISSI, 1987, p. 07-08).

Any effort at building a dialogical and open stance towards the contributions of both Western and non-Western women intellectuals and activists may be facilitated if we add culture - cultural encounters, to be more precise - as a relevant aspect of our discussions on gender and intersectionality. In this sense, Fatima Mernissi's double critical stance can be understood as an attempt at articulating an intersectional approach to gender which is attentive to the interplays of class, race, and culture, thus functioning as a gateway to a more historically situated understanding of what is at stake in islamic feminist approaches. An attention to non-Western voices and to the experiences of non-Western women - which includes but clearly is not limited to Muslim women - is a necessary step to decolonize the debate on gender and women's rights within feminist intellectual approaches and activism.

- Jessica da Silva C. de Oliveira é Professora na Pontificia Universidade Católica de Minas Gerais - Poços de Caldas. E-mail: jessicascoliveira@gmail.com.

\section{Referências}

ABU-LUGHOD, Lila. Do Muslim women really need saving? Anthropological reflections on cultural relativism and its others. American Anthropologist, v. 104, n. 3, p.783-790, 2002.

ACKERLY, Brooke; STERN, Maria; TRUE, Jaqui (Eds). Feminist methodologies for international relations. Nova York: Cambridge University, 2006.

AHMED, Leila. Women and gender in Islam: historical roots of a modern debate. New Haven: Yale University Press, 1992.

AKBARI-DIBAVAR, Aytak. Gender, race, and international relations. In: PERSAUD, Randolph B.; SAJED, Alina (Eds.). Race, gender, and culture in international relations: Postcolonial Perspectives. London/New York: Routledge, 2018. p. 58-79.

BADRAN, Margot. Islamic feminism: what's in a name? The Feminist eZine, [200-]. Available at: <http:/www.feministezine.com/feminist/international/Islamic-Feminism-01.html>. Accessed: March 30, 2021.

BASU, Amrita. Introduction. In: BASU, Amrita (Ed.). Women's movement in the Global Era: the power of local feminisms. $2^{\text {nd }}$ ed. Colorado: Westview Press, 2017. p. 1-33. 
BOURGET, Carine. Complicity with Orientalism in Third-World women's writing: Fatima Mernissi's Fictive Memoirs. Research in African Literatures, v. 44, n. 3, p. 30-49, 2013.

BRITTAIN, Melisa. Benevolent invaders, heroic victims and depraved villains: white femininity in media coverage of the invasion of Iraq. In: HUNT, Krista; RYGEL, Kim (Eds.). Engendering the war on terror. Burlington/Aldershot: Ashgate Publishing Co., 2006. p. 73-96.

COHN, Carol. Sex and death in the rational world of defense intellectuals. Signs, v. 12, n. 4, p. 687718, 1987. doi: 10.1086/494362

ENLOE, Cynthia. Bananas, beaches and basis: making feminist sense of international politics. $2^{\text {nd }}$ ed. Berkeley: University of California Press, 2014.

ENLOE, Cynthia. The curious feminist: searching for women in a new age of empire. Berkeley: University of California Press, 2004.

ESCOBAR, Aníbal. Encountering development: the making and unmaking of the third world. New Jersey: Princeton University Press, 1995.

FANON, Frans. A dying colonialism. New York: Grove Press, 1965.

HUNT, Krista. "Embedded feminism" and the war on terror. In HUNT, Krista; RYGEL, Kim (Eds.). Engendering the war on terror. Burlington/Aldershot: Ashgate Publishing Co., 2006. p. 51-72.

KAPOOR, Ilan, The queer third world. Third World Quarterly, v. 36, p. 1611-1628, 2015. doi: 10.1080/01436597.2015.1058148

KHATIBI, Abdelkebir. Double critique. In: KHATIBI, Abdelkebir. Maghreb pluriel. Paris/Rabat: Denöel, [1970] 1983. p. 43-112.

KROLOKKE, Charlotte. Three waves of feminism. In: KROLOKKE, Charlotte; SORENSEN, Anne Scott. Gender communication theories \& analyses: from silence to performance. London: Sage, 2006. p. $1-24$.

LAROUI, Abdallah. History of the Maghrib: an interpretive essay. New Jersey: Princeton University Press, 1977.

LORDE, Audre. Sister outsider: essays and speeches. Trumansburg, NY: Crossing Press, 1984.

MCCLINTOCK, Anne. Imperial leather: race, gender and sexuality in the colonial contest. New York: Routledge, 1995.

MERNISSI, Fatema. Scheherazade goes West: different cultures, different harems. New York: Washington Square Press, 2001.

MERNISSI, Fatema. Dreams of trespass: tales of a harem girlhood. New York: Addison-Wesley Publishing Co, 1994.

MERNISSI, Fatema. Doing daily battle: interviews with Moroccan women. New Brunswick/New Jersey: Rutgers University Press, 1989.

MERNISSI, Fatema. Beyond the veil: male-female dynamics in modern Muslim society. Bloomington: Indiana University Press, [1975] 1987.

MIGNOLO, Walter. The darker side of Western modernity: global futures, decolonial options. Durham: Duke University Press, 2011.

MOHANTY, Chandra Talpade. Under Western eyes: feminist scholarship and colonial discourses. Feminist Review, n. 30, p. 61-88, 1988.

MOGHADAM, Valentine M. Feminist movements in the Maghreb. In: BASU, Amrita (Ed.). Women's movement in the Global Era: the power of local feminisms. $2^{\text {nd }}$ ed. Colorado: Westview Press, 2017. p. 333-360. 
MUPPIDI, Himadeep. The colonial signs of international relations. Oxford: Oxford University Press, 2012.

OLIVEIRA, Jessica da Silva C. Postcolonial Maghreb and the limits of IR. London: Palgrave Macmillan, 2020.

OLIVEIRA, Jessica da Silva C. Repensando a fronteira entre Oriente e Ocidente: encontros culturais, narrativa e transgressão nos escritos de Fatema Mernissi. Monçóes: Revista de Relaçóes Internacionais da UFGD, v. 8, n. 15, p. 278-307, 2019. doi: https://doi.org/10.30612/rmufgd.v8i15.11547

PRATT, Nicola. How the West undermined women's right in the Arab World. Jadaliyya, Jan 25, 2016. Available at: <http://www.jadaliyya.com/pages/index/23693/how-the-west-underminedwomen's-rights-in-the-arab>. Accessed: August 19, 2021.

PATHAK, Zakiya; RAJAN, Rajeswari S. Shahbano. In: BUTLER, Judith; SCOTT, Joan W. (Eds.). Feminists theorize the political. London; New York: Routledge, 1992. p. 257-279.

RHOUNI, Raja. Secular and Islamic feminist critiques in the work of Fatima Mernissi. Leiden/Boston: Brill, 2010.

SAID, Edward. Orientalism. New York: Vintage Books, 1978.

SALEM, Sara. Feminist critique and Islamic feminism: the question of intersectionality. The Postcolonialist, v. 1, n. 1, 2013.

SHARP, Joanne P. Geographies of postcolonialism: spaces of power and representation. London; California: Sage Publications, 2006.

SPIVAK, Gayatri Chakravorty. Can the subaltern speak? In: WELSON, Cary; GROSSBERG, Larry (Eds.). Marxism and the interpretation of culture. Chicago: University of Chicago Press, 1988. p. 271313.

TICKNER, J. Ann. You may never understand: prospects for feminist futures in International Relations. The Australian Feminist Law Journal, v. 32, n. 1, p. 9-20, jun. 2010. doi: 10.1080/13200968.2010.10854434

TICKNER, J. Ann. You just don't understand: troubled engagements between feminists and IR theorists. International Studies Quarterly, v. 41, n. 4, p. 611-632, 1997.

TOHIDI, Nayereh. The women's movement and feminism in Iran: revisiting a "glocal perspective". In: BASU, Amrita (Ed.). Women's movement in the Global Era: the power of local feminisms. $2^{\text {nd }}$ ed. Colorado: Westview Press, 2017. p. 397-442.

WOODHULL, Winifred. Transfigurations of the Maghreb: feminism, decolonization, and literature. Minneapolis/London: The University of Minnesota Press, 1993.

ZAYZAFOON, Lamia Ben Youssef. The production of the Muslim woman: negotiating text, history, and ideology. Maryland: Lexington Books, 2005.

Texto recebido em 28 de outubro de 2021. Aprovado em 17 de novembro de 2021. 